\title{
Retinoblastoma Pathologic Regional Lymph Nodes TNM Finding v8
}

National Cancer Institute

\section{Source}

National Cancer Institute. Retinoblastoma Pathologic Regional Lymph Nodes TNM

Finding v8. NCI Thesaurus. Code C140709.

A pathologic finding about one or more characteristics of retinoblastoma, following the rules of the TNM AJCC V8 classification system as they pertain to staging of regional lymph nodes. 